\title{
Comparative floral anatomy of Rhynchospora consanguinea and Rhynchospora pubera (Cyperoideae, Cyperaceae)
}

\author{
Mariana M. Monteiro $^{1} \cdot$ Vera L. Scatena $^{1} \cdot$ Aline Oriani $^{1}$
}

Received: 29 July 2016/ Accepted: 21 November 2016/Published online: 9 December 2016

(C) Springer-Verlag Wien 2016

\begin{abstract}
Rhynchospora is one of the most species-rich genera of Cyperaceae and one of the few with entomophilous species. Considering the few anatomical studies of the genus, especially of the reproductive structures, this study comparatively analysed the anatomy of flowers of two representative species of Rhynchospora, $R$. consanguinea and $R$. pubera, including the floral vasculature and the anatomy of the style base, which is persistent with the fruit. Both species have congested inflorescences with light-coloured bracts and bisexual flowers, and phenolic idioblasts in the anthers and gynoecium, characteristics that suggest insect pollination. In $R$. consanguinea, the bisexual and the most proximal male flower has perianths, a new character state reported for the genus. The floral vasculature pattern is similar in both species, but differs from that previously described for Rhynchospora. In both species, there are two vascular bundles in the rachilla, which split into three receptacular bundles, the latter forming a vascular plexus where the bundles of stamens, gynoecium and ovule are connected. No lateral carpellary trace was observed, and the presence of the abaxial receptacular bundle was interpreted as a vestige of the tricarpellate ancestral condition. In the fruit of both species, the thickened style base (stylopodium) has a parenchyma with idioblasts containing phenolic compounds and idioblasts with helical or reticulate cell wall thickenings. The stylopodium is a homologous structure in the species of
\end{abstract}

Handling editor: Louis P. Ronse De Craene.

Mariana M. Monteiro

marimonteiro199@gmail.com

1 Departamento de Botânica, Instituto de Biociências,

Universidade Estadual Paulista (UNESP),

Caixa Postal 199, Rio Claro, SP 13506-900, Brazil
Rhynchospora and to other genera of Cyperoideae and evolved several times in the subfamily.

Keywords Cyperoideae - Floral vasculature · Pollination Rhynchospora $\cdot$ Style base

\section{Introduction}

The family Cyperaceae has a cosmopolitan geographical distribution and comprises ca. 5700 species and ca. 100 genera (Goetghebeur 1998; Govaerts et al. 2007; Stevens 2016). Two subfamilies, Mapanioideae and Cyperoideae, are recognised based on morphological and molecular data (Simpson et al. 2007; Muasya et al. 2009).

The inflorescence of Cyperoideae consists essentially of a panicle of spikelets, of which many derived forms occur (Goetghebeur 1998; Simpson et al. 2007; Muasya et al. 2009). Bisexual flowers in Cyperoideae show the typical floral plan of monocotyledons, consisting of two perianth whorls, two whorls each with three stamens and a tricarpellate gynoecium (Blaser 1941a, b; Goetghebeur 1998; Vrijdaghs et al. 2009; Reynders et al. 2012). Reduction in number of perianth parts, stamens and carpels as well as modifications of floral organs is common, leading to the variations in floral structure found in the subfamily (Blaser 1941a, b; Vrijdaghs et al. 2004, 2009). In many Cyperoideae, the outer perianth parts were reduced to vascularised bristle hairs due to an initial compression of the mesophyll, later followed by loss of the vascular system (Blaser 1941a, b). Isostemonous flowers derived from diplostemonous ones by loss of the inner whorl of stamens (Blaser 1941a, b; Vrijdaghs et al. 2005a, b, 2009), and the number of carpels was reduced from three to two (Blaser 1941a, b). The classic view on a cyperoid gynoecium is 
that it is tricarpellate, with two adaxially situated carpels and one abaxially situated carpel, which often is reduced or even absent (Blaser 1941a, b).

Rhynchospora, one of the most species-rich genera of Cyperaceae (Simpson et al. 2007; Muasya et al. 2009), is included in the subfamily Cyperoideae and comprises ca. 300 species (Thomas 2009), occurring mainly in tropical America (Thomas 1984, 1992; Araújo 2001; Guaglianone 2001; Strong 2006). The genus has paniculate or capitate inflorescences (Eiten 1976; Thomas 1992; Guaglianone 2001; Strong 2006; Lucero and Vegetti 2012), subtended by foliaceous involucral bracts, which can be entirely green or white, or white towards the base and green distally (Araújo 2001). It is the composition of the spikelets that distinguishes the species of Rhynchospora from the rest of the Cyperaceae. Each spikelet is either made up entirely of bisexual flowers or consists of a single proximal bisexual flower and three to twelve distal male flowers (Thomas 1992; Guaglianone 2001; Strong 2006; Lucero et al. 2014). The glumes are spirodistichally arranged with one to three proximal sterile glumes and the rest fertile. Lucero et al. (2014) described a new spikelet type for the genus, composed of a single proximal female flower and several distal male flowers. The bisexual flowers usually have a perianth consisting of five so-called bristle hairs, three stamens, a dimerous gynoecium and a uniovulate ovary with basal placentation; the style has a thickened base, which is persistent with the fruit (Goetghebeur 1998; Guaglianone 2001; Strong 2006). The genus is also outstanding in Cyperoideae in its tendency to shift from wind pollination (which is the usual condition in the family) to insect pollination (Thomas 1984; Lucero et al. 2014). Rhynchospora is one of a few genera of the family which includes species with morphological features that suggest insect pollination, such as white involucral bracts and glumes, sticky pollen and congested spikelets composed of bisexual and protandrous flowers (Thomas 1984; Leppik 1995; Wragg and Johnson 2011; Costa and Machado 2012; Lucero et al. 2014). Therefore, anatomical studies of the flowers of Rhynchospora may contribute to test the hypothesis of insect pollination.

Rhynchospora was formerly divided into two subgenera, Haplostyleae (comprising the species with an undivided or shallowly divided style) and Rhynchospora (previously described as Diplostyleae, comprising species with a deeply divided style) (Kükenthal 1949, 1950, 1951, 1952). However, the phylogenetic analysis of the tribe Rhynchosporeae based on molecular data showed two wellsupported main clades (clade A and clade B), one comprising species of Haplostyleae, but the other comprising species of both subgenera (Thomas et al. 2009). Rhynchospora consanguinea (Haplostyleae) and $R$. pubera (Rhynchospora) are included in each of these clades and have morphological characteristics related to insect pollination, such as capitate inflorescences with light-coloured glumes (Araújo 2001; Strong 2006). Moreover, species of Trigona were observed visiting the inflorescences of $R$. pubera (Thomas 1984).

An informative characteristic for the taxonomy of Rhynchospora is the presence of a thickened style base, which is persistent with the fruit (Kukkonen 1984; Thomas 1984; Araújo 2001; Strong 2006). The style bases exhibit morphological variation, which can be used to distinguish among the species and subsections (Araújo et al. 2003; Strong 2006). A thickened style base occurs not only in Rhynchospora but also in other Cyperoideae genera such as Bulbostylis Kunth, Fimbristylis Vahl, Abildgaardia Vahl, Eleocharis R.Br. and Fuirena Rottb. (Thomas 1992; Bruhl 1995; Goetghebeur 1998; Araújo et al. 2003; Vrijdaghs et al. 2004; Gil and Bove 2007; Swan and Richards 2007; Gonzalez and López 2010; Reutemann et al. 2012). The anatomy of cyperoid style bases has been described for species of Abildgaardia, Bulbostylis and Fimbristylis, in which they are homologous and histologically simple (Reutemann et al. 2012). In these genera, although the style base may be persistent with the fruit or deciduous, it does not have any abscission layer and, according to Reutemann et al. (2012), a lower number of sclerified cells may be responsible for its short duration in some species.

Although there are several anatomical studies of vegetative organs of Rhynchospora (e.g. Govindarajalu 1969; Metcalfe 1969; Thomas 1984; Martins et al. 2012; Martins and Scatena 2011; Lucero et al. 2014), for the floral anatomy there is few available information (e.g. Baillon 1893; Snell 1936; Saunders 1937; Blaser 1941a, b; Reynders et al. 2012). Blaser (1941a, b) included species of Rhynchospora and other Cyperoideae genera in a wide spectrum study about the floral vasculature in the subfamily and concluded that his observations showed evidence of reduction in perianth parts, stamens and the abaxial third carpel. For Rhynchospora, the author described the presence of peripheral lateral carpellary traces and interpreted them as vestiges of the aborted abaxial carpel (Blaser 1941b). Reynders et al. (2012) also studied the floral vasculature and development in Cyperoideae species with different types of gynoecium (trimerous, dorsiventrally flattened dimerous and laterally flattened dimerous) and showed the absence of carpel primordia and instead the presence of an annular ovary wall primordium surrounding a central meristematic tissue from which the single ovule is formed. According to the authors, the absolute fusion of the evolutionary original carpels into one annular primordium in combination with the bidirectional development of the gynoecium vasculature allows developmental freedom to form the different gynoecium types found in the subfamily, which thus cannot be explained by carpel reduction. 
In this context, a comparative study on floral anatomy of $R$. consanguinea and $R$. pubera was made, aiming to answer the following questions: 1) Considering that the species belong to distinct main clades of Rhynchospora, which anatomical characteristics are shared by them and are suggestive for insect pollination? 2) Are the style bases in the two studied species homologous to each other and to other style bases in Cyperoideae? 3) Considering that both species have a dorsiventrally flattened dimerous gynoecium, does the pistil vasculature pattern corroborate the hypothesis of Blaser (1941a, b) or that of Reynders et al. (2012) about the origin of this type of gynoecium?

\section{Materials and methods}

The samples of $R$. consanguinea (Kunth) Boeckeler were collected from the Parque Nacional da Serra do Cipó (Santana do Riacho, Minas Gerais, Brazil), in areas with rocky outcrop vegetation, and the samples of $R$. pubera (Vahl) Boeckeler were collected from the Reserva Florestal Adolpho Ducke (Manaus, Amazonas, Brazil), in the moist understorey of the Amazon rainforest. Vouchers of the collected material were identified and deposited in the Herbarium Rioclarense (HRCB) at Universidade Estadual Paulista (Coan et al. number 17). The inflorescences were fixed in FAA $50 \quad(37 \%$ formaldehyde, glacial acetic acid, 50\% ethanol, 1:1:18 v/v) (Johansen 1940) for morphological and anatomical studies.

For the anatomical study, inflorescences at different developmental stages were subjected to a $n$-butyl alcohol dehydration series, infiltration and inclusion in (2-hydroxyethyl)-methacrylate (Leica Historesin Embedding Kit, Nussloch, Germany) (Gerrits and Smid 1983). The embedded material was sectioned at 5-7 $\mu \mathrm{m}$ on a rotation microtome (Leica RM 2245, Nussloch, Germany), stained with periodic acid-Schiff's reagent (PAS) and toluidine blue (O'Brien et al. 1964; Feder and O'Brien 1968) and mounted on permanent slides with Entellan (Merck, Darmstadt, Germany). Photomicrographs were obtained with a LAS (Leica Application Suite V 4.0.0) digital imaging system, using an image-capturing device (Leica DFC 450, Heerbrugg, Switzerland) coupled to a microscope (Leica DM4000B, Wetzlar, Germany).

For scanning electron microscopic (SEM) study of the style base, mature fruits were dehydrated through an alcohol series, $\mathrm{CO}_{2}$ critical point dried (Balzers CPD 030, Liechtenstein), coated with gold (Bal-Tec SCD 050, Liechtenstein) and examined in a scanning electron microscope (Hitachi TM 3000, Krefeld, Germany). The results were recorded using the TM 3000 Application Program.

\section{Results}

\section{Floral morphology and anatomy}

In both species, each spikelet (the reproductive unit of the inflorescence) consists of an indeterminate rachilla with acropetally developing glumes, each subtending (or not) a single flower. Rhynchospora consanguinea has lateral spikelets with proximally and adaxially positioned a prophyll, and higher up in the spikelet one sterile glume followed by pale fertile glumes (Fig. 1b). Each spikelet is composed of a proximal bisexual flower (Fig. 1a-arrow) and 3-12 distal, strictly male flowers, each with three stamens (Fig. 1a). The bisexual flower has a perianth composed of five bristle hairs
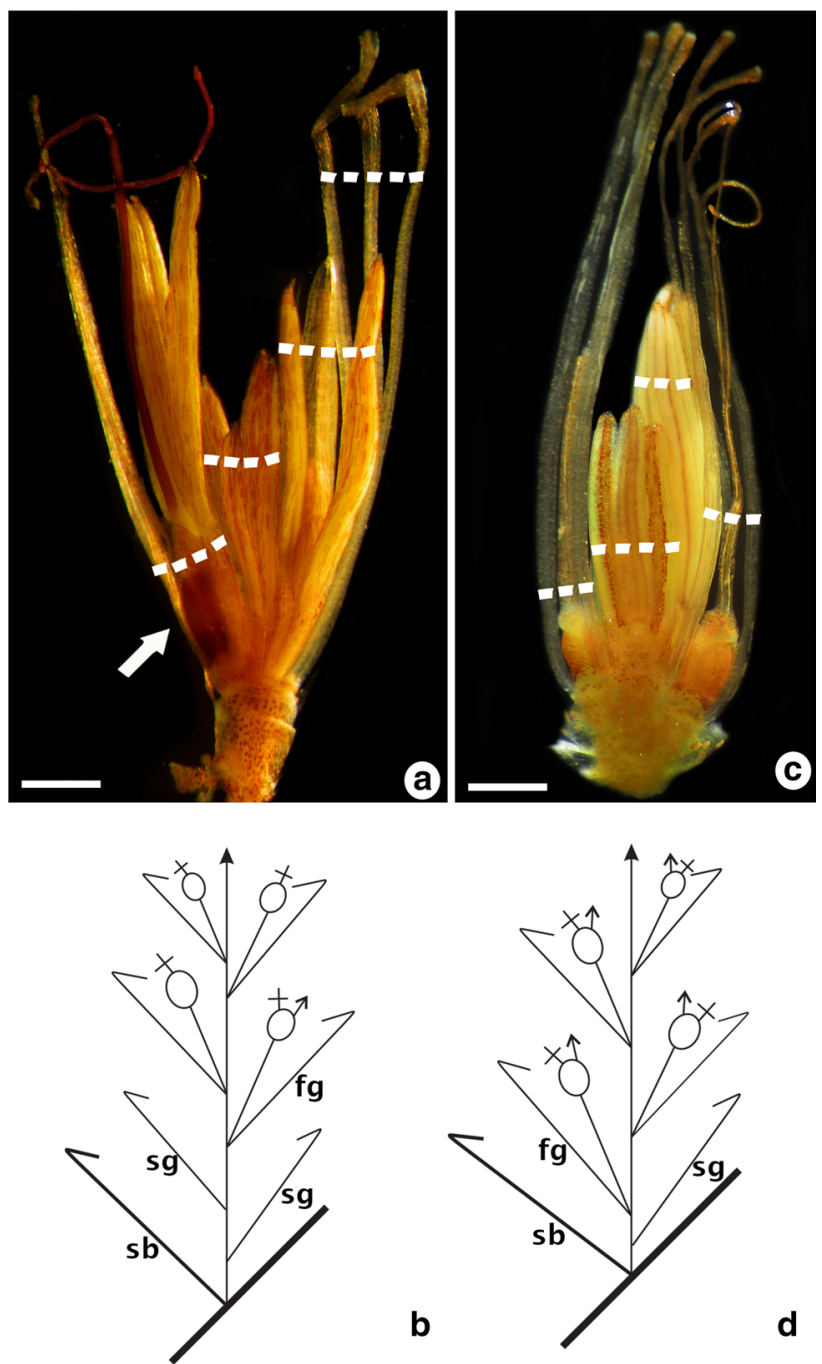

d

Fig. 1 Structure of the spikelets of Rhynchospora consanguinea and $R$. pubera. a, b $R$. consanguinea. a Spikelet with bract and glumes removed to show the proximal bisexual flower (arrow) and the distal male flowers. b Axial scheme of a spikelet. c, d $R$. pubera. c Spikelet with bract and glumes removed to show the bisexual flowers. d Axial scheme of a spikelet. $f g$ fertile glume, $s b$ spikelet bract, $s g$ sterile glume. Scale bars $\mathbf{a}-\mathbf{d}=1 \mathrm{~mm}$ 
(two in the outer whorl and three in the inner whorl), three stamens (two adaxial and one abaxial) and one gynoecium with a shortly divided style. The most proximal male flower has a perianth composed of two bristle hairs and three stamens; the remaining male flowers of the spikelet lack a perianth.

Rhynchospora pubera has lateral spikelets with a proximal and adaxial a prophyll, and higher up in the spikelet four to five white fertile glumes, each subtending a bisexual flower (Fig. 1c, d). The flowers are perianthless and have three stamens and one gynoecium with a deeply divided style.

The perianth parts of bisexual and most proximal male flower of $R$. consanguinea consist of epidermal cells with cell wall projections (Fig. 2a), parenchyma, and lack a vascular system (Fig. 2b).

In both species, the filaments consist of a single-layered epidermis, parenchyma and one single vascular bundle (Fig. 2c) that runs to the connective (Figs. 2d-e, 3a). The anthers are tetrasporangiate and basifixed, with longitudinal dehiscence, latrorse in $R$. consanguinea (Fig. 2e) and introrse in R. pubera (Fig. 3a). In both species, the anther wall consists of a single-layered epidermis, an endothecium without thickenings, a middle layer and a tapetum in the immature anthers (Fig. 2d); when the anthers are mature, their walls consist of only epidermis and an endothecium with spiral thickenings (Figs. 2e, 3a). In $R$. consanguinea, some cells of the connective contain phenolic compounds (Fig. 2d-e), and in $R$. pubera these phenolic compounds are concentrated in the epidermal cells above the connective (Fig. 3a).

The bisexual flowers of both species have a superior, syncarpous, unilocular ovary (Figs. $2 \mathrm{f}-\mathrm{g}, 3 \mathrm{~b}-\mathrm{c}$ ) with basal placentation. The outer epidermis of the ovary wall is composed of anticlinally elongated cells with thin walls and phenolic compounds; the inner epidermis has periclinally elongated cells with thin walls (Figs. $2 \mathrm{f}-\mathrm{g}, 3 \mathrm{~b}-\mathrm{c}$ ). The ovary mesophyll consists of two to five layers of parenchymatous rounded cells and is vascularised by two vascular bundles that are situated laterally in the dorsiventrally flattened ovary wall (Figs. 2g, 3c) and run through the style up to the stigmas (Figs. 2h-i, 3d-f). The style has rounded thin-walled epidermal cells and parenchyma surrounding the pollen tube transmission tissue (Figs. 2h, 3d). The stigmas consist of rounded epidermal cells that have thin walls (Figs. 2i, 3ef). Phenolic compounds are present in all of the epidermal cells of style and stigmas of $R$. consanguinea (Fig. $2 \mathrm{~h}-\mathrm{i}$ ) and only in some of them in R. pubera (Fig. 3d-f).

\section{Anatomical features of the style base}

The style base is persistent with the fruit in both species, but they are morphologically distinct. In $R$. consanguinea, the style base is triangular with angular edges (Fig. 4a). In $R$. pubera, the style base is strap-shaped with rounded edges and covers the distal part of the fruit (Fig. 4b). Anatomically, the style bases of both species have epidermal cells with the outer periclinal walls thicker than the inner ones, parenchymatous tissue, idioblasts with phenolic contents and idioblasts with thickened cell walls (Fig. 4c-e). In $R$. consanguinea, the idioblasts with thickened cell walls are scattered throughout the style base (Fig. 4c, d-arrows), and in R. pubera these idioblasts are concentrated at the base of the style base (Fig. 4d-dotted line). These idioblasts may be long or short, with helical or reticulate thickenings (Fig. 4f, g).

\section{Floral vasculature}

The vasculature of the spikelet is similar in both species and was illustrated for $R$. consanguinea (Fig. 5). In the axis of the spikelet, there is a ring of vascular complexes (Fig. 5a) from which the traces of the glumes and flowers arise. After the divergence of the most distal sterile glume trace (sg) (Fig. 5a), the trace of the glume subtending the bisexual flower (gbf) diverges (Fig. 5b) and, opposite it, the trace of the glume subtending the most proximal male flower (gmf) (Fig. 5c). More distally, the distinction between the vascular supply of the bisexual (bf) and male flowers (mf) becomes evident (Fig. 5c-d). Each flower is supplied by two vascular bundles (Fig. 5d) that split into three bundles at the level of the receptacle (receptacular bundles) (Figs. 5d, 6a, 7a).

In the bisexual flower of $R$. consanguinea, the five perianth parts are not vascularised. The two outer perianth parts are opposite the adaxial stamens (Fig. 6e-h-arrows), and the three inner ones are alternating with the stamens (Fig. 6f-h-arrowheads).

In both species, the three receptacular bundles expand, forming an annular central vascular plexus (Figs. 6b, 7b), from which the staminal and carpellary traces arise. The staminal traces are the first to diverge from the central vascular plexus, in the same position of the former receptacular bundles (Figs. 6c-d, 7c). Each staminal bundle runs through a filament (Figs. 6e-h, 7e-h) to the connective. Subsequently two carpellary traces branch off from the central vascular plexus (Figs. 6e-g, 7d-f) and run through the ovary wall in lateral positions up to the stigmas, corresponding to the dorsal carpellary bundles (Figs. 6h, 7gh). At a level above the divergence of the dorsal carpellary bundles, the central vascular ring, which corresponds to the ventral carpellary bundles (Figs. $6 f-g, 7 e-f$ ), supplies the single ovule (ovule bundle) (Figs. 6h, 7h).

\section{Discussion}

\section{Floral morphology and anatomy}

Besides the division of the style, the main differences between the species studied are: the presence of perianth in 
Fig. 2 Anatomical aspects of the flowers of Rhynchospora consanguinea. a Longitudinal section (LS) of a perianth part of the bisexual flower.

b Transverse section (TS) of a perianth part of the bisexual flower. $\mathbf{c}$ TS of the filament. d TS of the young anther. e TS of the mature anther. $\mathbf{f}$ LS of the ovary. g TS of the ovary. h TS of the style. i TS of the stigmas. $e$ epidermis, $e n$ endothecium, $m l$ middle layer, $t$ tapetum, sty style base, $d b$ dorsal carpellary bundle, $o b$ ovule bundle, $t t$ transmission tissue. Scale bars $\mathbf{a}, \mathbf{b}, \mathbf{c}, \mathbf{d}, \mathbf{e}, \mathbf{g}, \mathbf{h}, \mathbf{i}=25 \mu \mathrm{m}$; $\mathbf{f}=50 \mu \mathrm{m}$
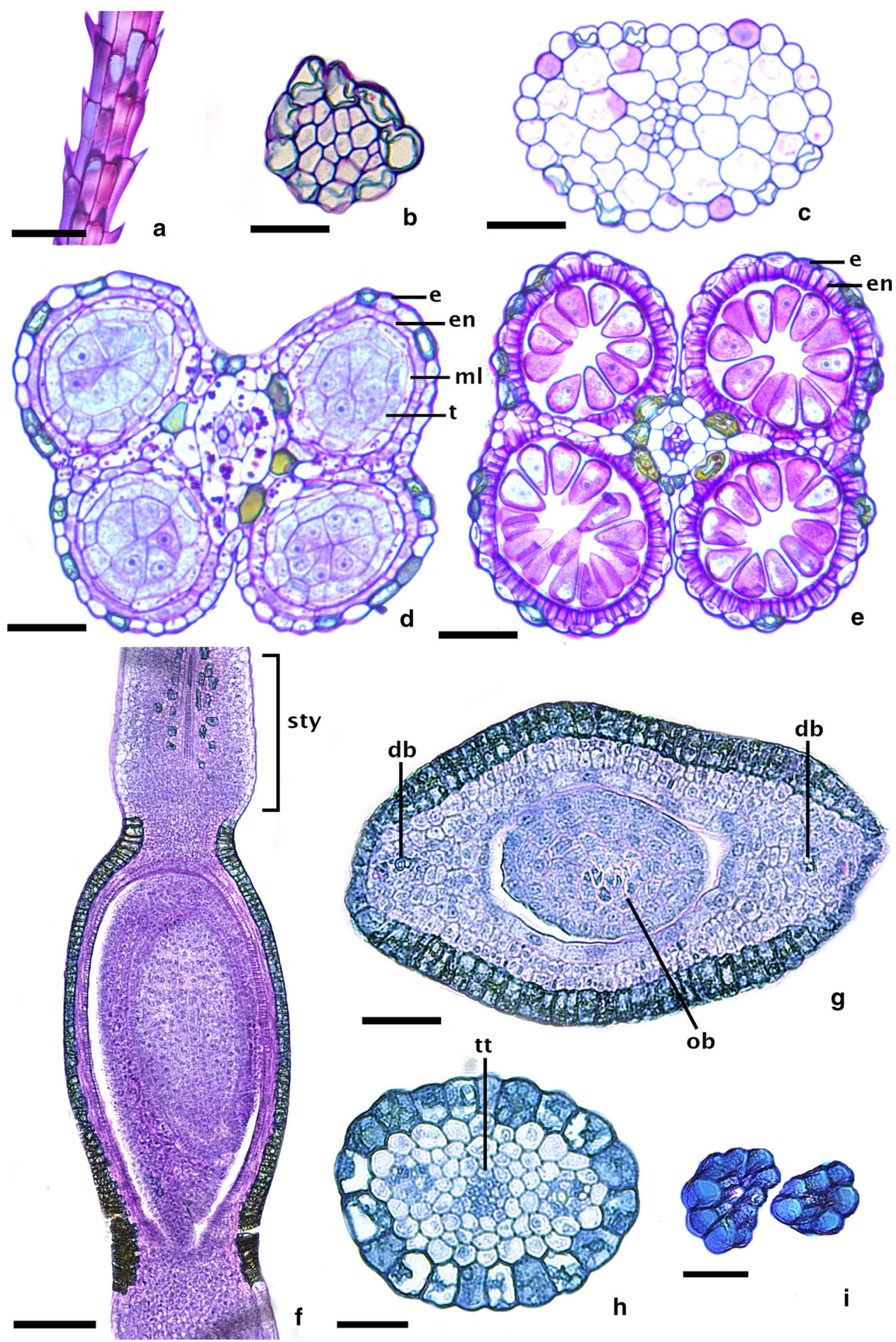

the bisexual and in the most proximal male flower of $R$. consanguinea, and the anther dehiscence.

The perianth parts of $R$. consanguinea are modified to bristle hairs and are not vascularised, characteristics interpreted as a derived condition. Species of Rhynchospora studied by Blaser (1941b) (R. macrostachya, $R$. glomerata, $R$. capillacea, $R$. inexpansa and $R$. alba) all possess vascularised perianth parts. Rhynchospora is one of a few genera of Cyperaceae that include species both with and without perianth (Blaser 1941b; Goetghebeur 1998) and, according to Lucero et al. (2014), flowers with perianths evolved at least twice in the genus.

Lucero et al. (2014) described three character states for Rhynchospora: spikelets with all flowers with perianth; 


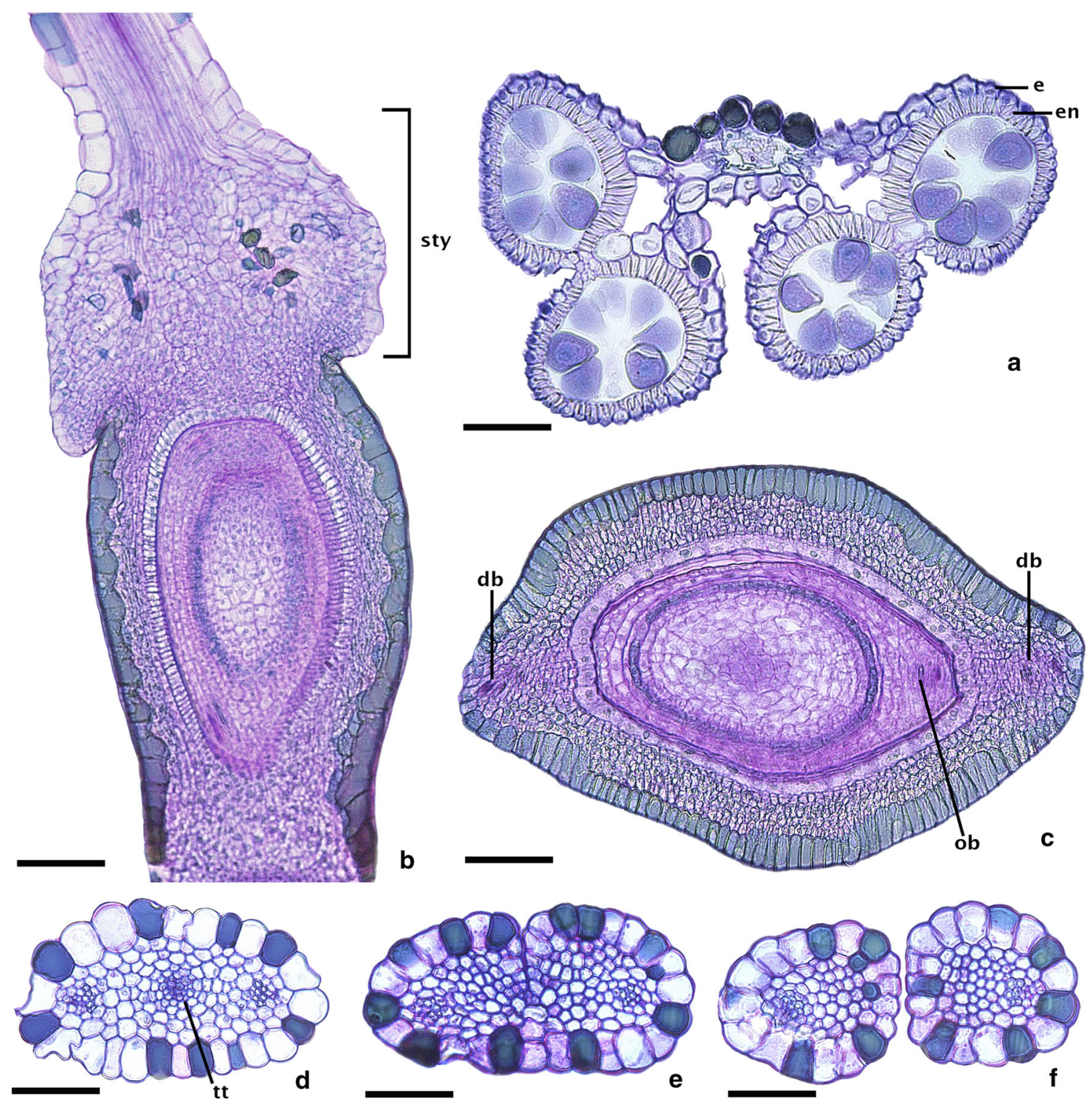

Fig. 3 Anatomical aspects of the flowers of Rhynchospora pubera. a Transverse section (TS) of the mature anther. b Longitudinal section (LS) of the ovary. c TS of the ovary. d TS of the style. e, f TS of the

spikelets with only the proximal flower with perianth; and spikelets with all flowers without perianth. However, based on our results, we report here a new character state for $R$. consanguinea, which is the presence of perianth in the bisexual flower and also in the most proximal male flower.

The absence of one of the outer perianth parts in $R$. consanguinea was also reported by Lucero et al. (2014); however, given that they examined only one specimen, they could not be certain that this was a stable condition. The reduction on number and structure of perianth parts is commonly reported for Cyperaceae (Blaser 1941a, b; Vrijdaghs et al. 2005a, b, 2009), and in the present study we verified that the absence of the outer abaxial perianth stigmas. $e$ epidermis, en endothecium, sty style base, $d b$ dorsal carpellary bundle, $o b$ ovule bundle, $t t$ transmission tissue. Scale bars $\mathbf{a}, \mathbf{c}, \mathbf{d}, \mathbf{e}, \mathbf{f}=25 \mu \mathrm{m} ; \mathbf{b}=50 \mu \mathrm{m}$

part in $R$. consanguinea is a stable condition, confirming the occurrence of organ abortion in this species.

Another feature that differentiates the species studied is the anther dehiscence, which is latrorse in $R$. consanguinea and introrse in $R$. pubera. Such differences are reported here for the first time and could be informative for taxonomy; however, anatomical analyses of other species of Rhynchospora are required.

\section{Anatomical evidence related to pollination}

Cyperaceae have characteristics as reduced flowers with long stigmatic branches, elongated filaments and anthers 

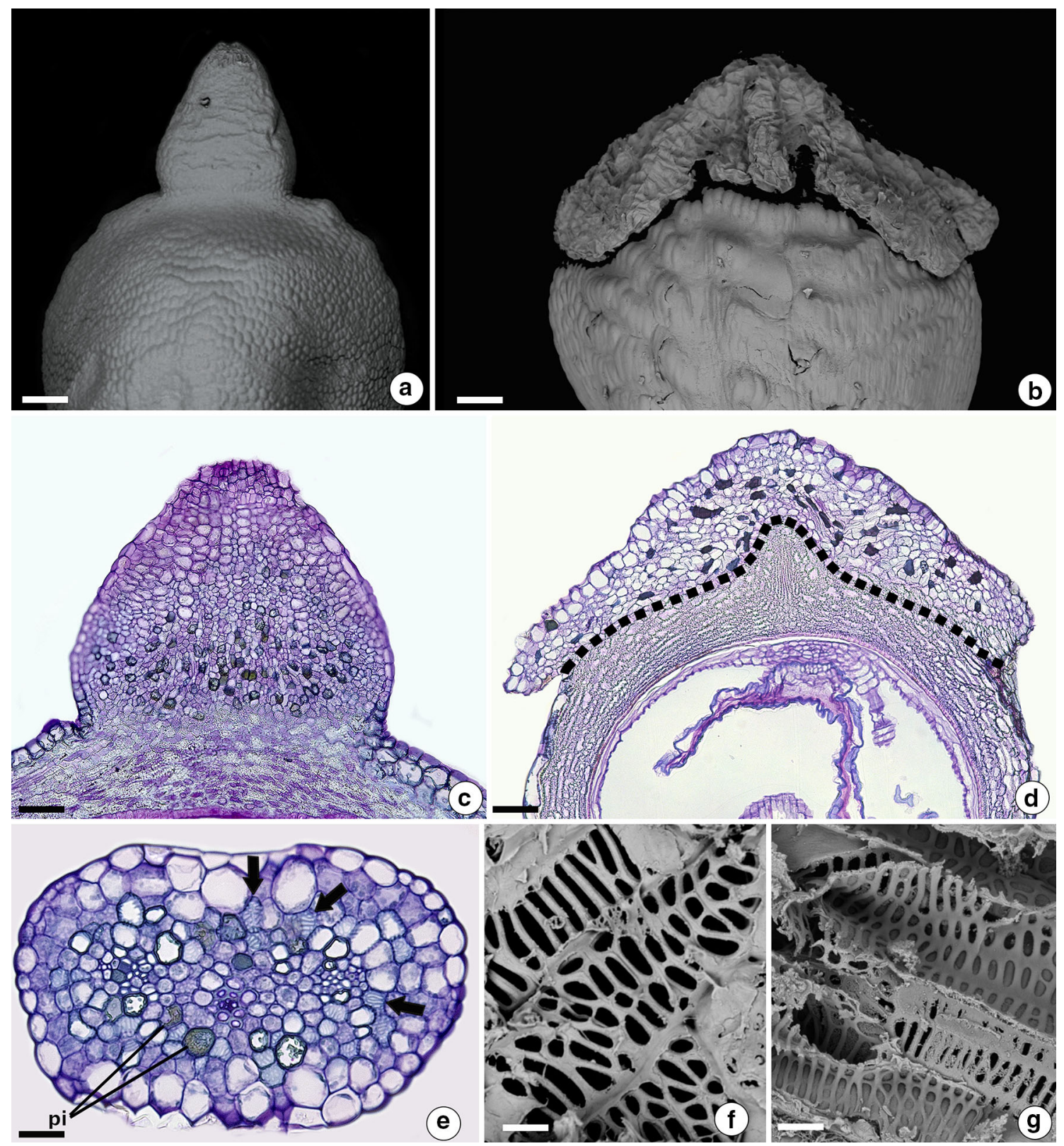

Fig. 4 Anatomy and micromorphology of the stylopodium of Rhynchospora consanguinea and $R$. pubera. a, b SEM micrograph showing stylopodium in the mature fruit of a $R$. consanguinea and b $R$. pubera. c, d Longitudinal section (LS) of the stylopodium in the mature fruit of (c) $R$. consanguinea and $\mathbf{d} R$. pubera. e Transverse section (TS) of the stylopodium in the mature fruit of $R$. consanguinea

with abundant pollen, which are related to anemophily, found in the majority of the members of Cyperaceae (Leppik 1995; Goetghebeur 1998; Wragg and Johnson 2011). However, entomophily has been recorded in genera as Rhynchospora, Carex, Cyperus, Eleocharis, Ficinia (Goetghebeur 1998; Magalhães et al. 2005; Wragg and Johnson 2011; Costa and Machado 2012), as well as in Mapanioideae species (Wragg and Johnson 2011). showing the idioblasts with thickened cell walls (arrows) and idioblasts containing phenolic compounds. f, g SEM micrographs showing details of the idioblasts with thickened cell walls (helical or reticulate thickenings) in $\mathbf{f} R$. consanguinea and $\mathbf{g}$. pubera. pi phenolic idioblast. Scale bars $\mathbf{a}, \mathbf{b}=0.25 \mathrm{~mm} ; \mathbf{c}, \mathbf{d}, \mathbf{e}=50 \mu \mathrm{m} ; \mathbf{f}$, $\mathbf{g}=4.1 \mu \mathrm{m}$

The traits related to entomophily in Cyperaceae are based mainly on morphological features as white involucral bracts and/or glumes, sticky pollen and bisexual spikelets (Thomas 1984; Goetghebeur 1998; Lucero et al. 2014). Rhynchospora consanguinea has congested inflorescences surrounded by involucral bracts that are white towards the base and the glumes are pale. In R. pubera, the involucral bracts are entirely green; however, the congested 

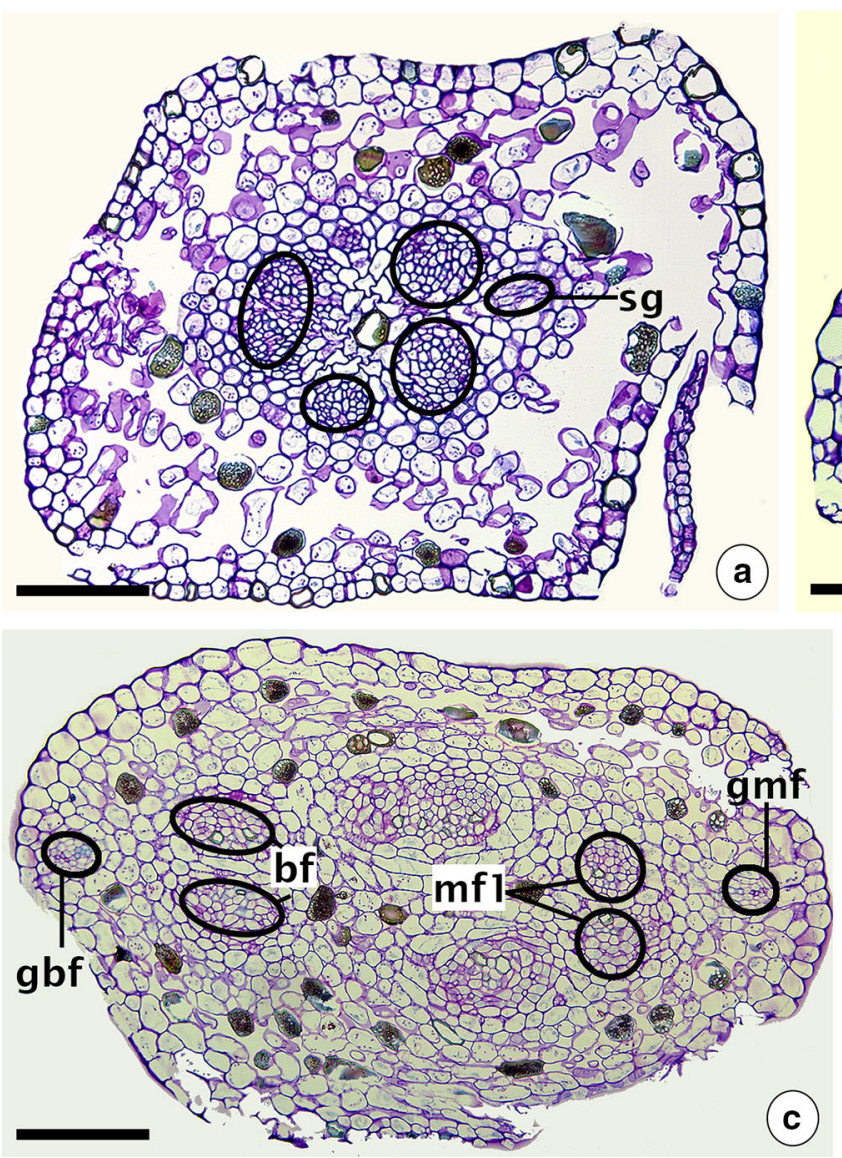

Fig. 5 Transverse sections from base to apex of the spikelet axis of Rhynchospora consanguinea, showing the organisation of the bundles. a Spikelet axis showing a ring of vascular complexes. b Divergence of the vascular trace of most distal sterile glume opposite to the vascular trace of the glume that subtends the bisexual flower. c Divergence of the vascular traces of male flowers. d The

inflorescences have white glumes, characteristics that suggest insect pollination. The light-coloured bracts make the inflorescences more conspicuous to insects and their form permits the pollinator to collect more pollen and visit more flowers in a short period of time, as reported for other genera of Cyperaceae such as Cyperus, Ficinia and Carex (Thomas 1984).

The anatomical features of the flowers of both species are very similar and also suggest insect pollination. In both species, the flowers have idioblasts with phenolic compounds in the ovary, style, stigmas and anthers, which may indicate entomophily. The presence of such idioblasts may be associated with the volatilisation of odours important in the attraction of pollinators (Dobson and Bergström 2000). The presence of floral volatiles has already been reported for Eleocharis elegans (Magalhães et al. 2005) and species of Cyperus (Wragg and Johnson 2011) and related to attraction of pollinators.
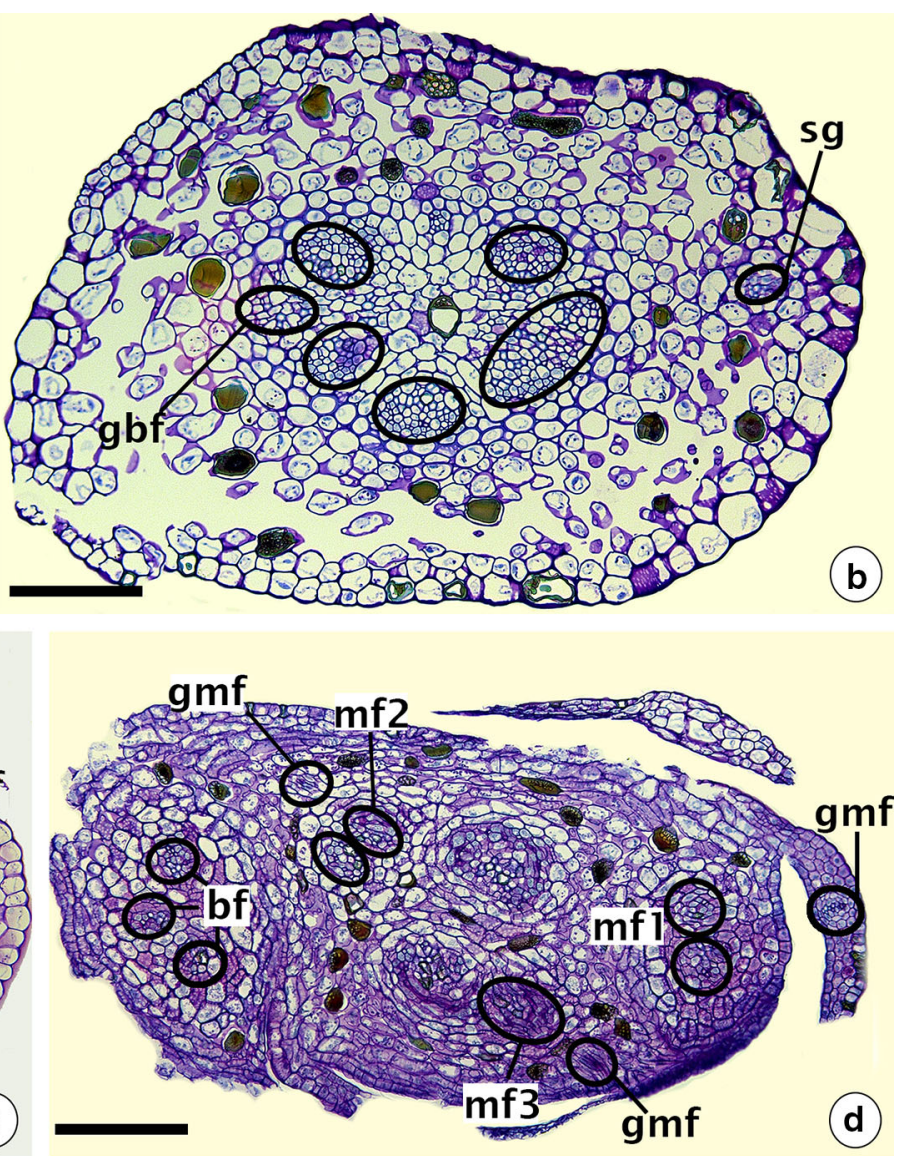

vascular bundles of the bisexual flower split into three receptacular bundles. $s g$ vascular trace of sterile glume, $g b f$ vascular trace of the glume that subtends the bisexual flower, $g m f$ vascular trace of the glume that subtends a male flower, $b f$ vascular supply of bisexual flower, $m f$ vascular supply of male flowers. Scale bars a, b, c, $\mathbf{d}=50 \mu \mathrm{m}$

Fig. 6 Transverse sections from the base to apex of the bisexual flower of Rhynchospora consanguinea. a Receptacular bundles at the floral receptacle. $\mathbf{b}$ Vascular plexus forming a ring. $\mathbf{c}, \mathbf{d}$ Divergence of the vascular traces of stamens. e Divergence of the dorsal carpellary traces and differentiation of the two outer perianth parts (arrows) opposite to the adaxial stamens. f, $g$ Differentiation of the inner perianth parts alternating with the stamens (arrowheads). The remnants of central vascular plexus correspond to the ventral carpellary bundles, which will supply the single ovule. h ST of the flower in the median region of gynoecium, showing the perianth parts, filaments, ovary wall vascularised by two dorsal carpellary bundles and the single ovule. $d b$ dorsal carpellary bundle, $d t$ dorsal carpellary trace, $o b$ ovule bundle, $r b$ receptacular bundle, $s b$ staminal bundle, $s t$ staminal trace, $v p$ central vascular plexus. Scale bars $\mathbf{a , ~ b , ~ c , ~ d , ~ e , ~ f , ~ g , ~}$ $\mathbf{h}=25 \mu \mathrm{m}$

Rhynchospora pubera belongs to the section Dichromena, which was extensively studied by Thomas (1984) who observed the inflorescences being visited by beetles, bees and syrphid flies. According to this author, the white 

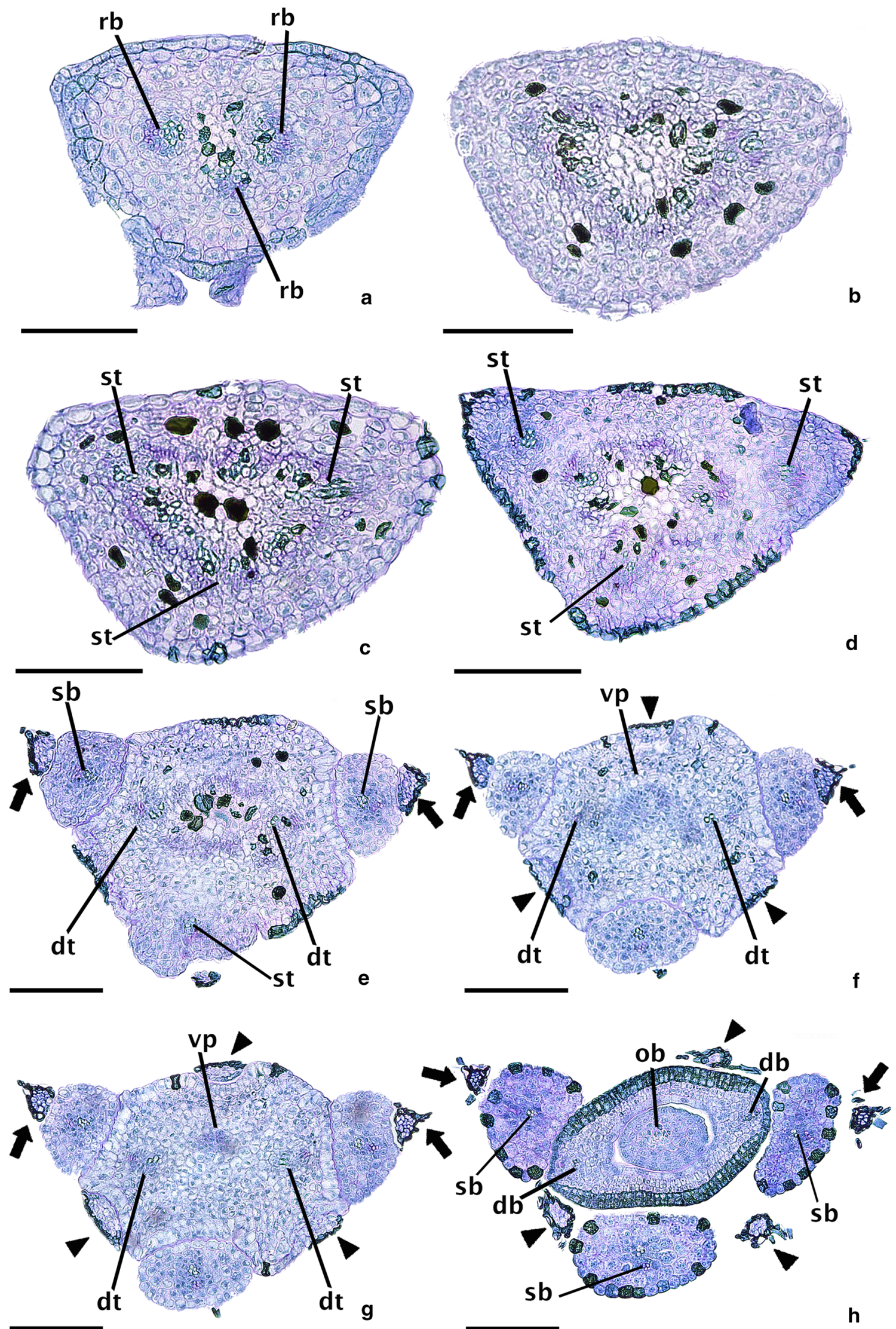
glumes and sticky pollen are traits that indicate the transition from anemophily to entomophily in these species. Although entomophily was not reported for other species of Rhynchospora, besides those from section Dichromena, in this study attention is drawn to $R$. consanguinea, belonging to a subgenus with no report of entomophily but presenting morphological and anatomical floral features that suggest insect pollination. Since most species of Rhynchospora has congested inflorescences with white involucral bracts or glumes (Thomas 1984; Strong 2006), we believe that insect pollination is a common condition or has arisen multiple times in the genus.

\section{Anatomical features of the style base}

The style base showed to be morphologically different in the species studied. The difference in the shape of the style base has already been reported by Thomas (1984) as a critical taxonomic feature for delimitation of Rhynchospora species.

The presence of a thickened style base is not unique to Rhynchospora and has been reported for other genera of Cyperoideae, such as Fuirena (Vrijdaghs et al. 2004), Eleocharis (Vrijdaghs et al. 2009), Bulbostylis (Gonzalez and López 2010; Reutemann et al. 2012), Abildgaardia and Fimbristylis (Reutemann et al. 2012). In species of Fuirena, the style base corresponds to a constriction of the upper part of the ovary (Vrijdaghs et al. 2004). However, in $R$. consanguinea and $R$. pubera, as well as in species of Eleocharis, Bulbostylis, Abildgaardia and Fimbristylis (Vrijdaghs et al. 2009; Gonzalez and López 2010; Reutemann et al. 2012), the style bases have the same origin (from the base of the style) and share anatomical features as the presence of idioblasts with phenolic compounds and idioblasts with helical or reticulate cell wall thickenings (termed tracheids by previous authors) (Gonzalez and López 2010; Reutemann et al. 2012), indicating that they are morphologically homologous. Since the style base does not correspond to the same structure among the cyperids, we suggest the use of the term "stylopodium" for the style base with a stylar origin, as previously termed by Kukkonen (1984).

Considering the occurrence of the stylopodium in not closely related genera, it can be inferred that such structure has evolved several times during the evolution of the family. If its occurrence is evaluated in the phylogenetic hypothesis of Muasya et al. (2009), it can be showed that the stylopodium appeared several times in Cyperoideae: in Rhynchospora, in some genera of Abildgaardieae and in Eleocharis (Fig. 8).

The stylopodium can be persistent with the mature fruit, after the detachment of the upper part of the style, as in the species of Rhynchospora, or it can detach together with the
Fig. 7 Transverse sections from base to apex of the flower of Rhynchospora pubera. a Receptacular bundles at the floral receptacle. b Vascular plexus forming a ring. c Divergence of staminal traces. d, e, f Divergence of the dorsal carpellary traces. $\mathbf{g}$ ST of the flower at base of gynoecium, showing the filaments and the ovary wall vascularised by the two dorsal carpellary bundles. $\mathbf{h}$ ST of the flower in the median region of gynoecium, showing the filaments, ovary wall vascularised by two dorsal carpellary bundles and the single ovule. $d b$ dorsal carpellary bundle, $d t$ dorsal carpellary trace, $o b$ ovule bundle, $r b$ receptacular bundle, $s b$ staminal bundle, st staminal trace, $v p$ central vascular plexus. Scale bars $\mathbf{a}, \mathbf{b}, \mathbf{c}, \mathbf{d}, \mathbf{e}, \mathbf{f}, \mathbf{g}, \mathbf{h}=25 \mu \mathrm{m}$

upper part of the style, not persisting with the fruit, as in species of Bulbostylis, Abildgaardia and Fimbristylis (Reutemann et al. 2012). While the presence of a persistent stylopodium may have arisen multiple times in Cyperoideae, a deciduous stylopodium appears to be an apomorphy of Abildgaardieae (Fig. 8).

In species of Abildgaardia and Fimbristylis, the presence of a deciduous stylopodium was related to the lower number of sclerified cells that make up such structure in the mature fruit, being the abscission of the stylopodium a result of mechanical shear effects upon the sclerified cells (Reutemann et al. 2012). Our results, however, show that in the stylopodium of $R$. consanguinea and $R$. pubera there are no sclerified cells, even in the mature fruit; therefore, the persistence of the stylopodium is not related to the amount of sclerified cells, as suggested by Reutemann et al. (2012).

The function of the stylopodium remains uncertain, being reported as a region where selection of pollen tubes takes place (Reutemann et al. 2012), a structure that protects the ovary apex (Reutemann et al. 2012), or a structure related to fruit dispersal (Vrijdaghs et al. 2009). Gonzalez and López (2010) attributed to the cells with helical cell wall thickenings (tracheids) of the stylopodium of Bulbostylis the function of water uptake for seed germination. These helical tracheoidal cells were also reported for orchid seeds as part of the mechanism of water uptake (Prutsch et al. 2000). However, Reutemann et al. (2012) discarded such hypothesis since these cells are also present in the deciduous stylopodium of Abildgaardia and Fimbristylis, in whose species they do not play such role. Here, we hypothesise that the stylopodium plays a function in pollination, since this structure may contribute as a mechanical support for the style, keeping it erect during anthesis and projecting it beyond the extremely congested spikelet. This function is especially important for the transition to insect pollination, giving a mechanical strength to the style during the contact of the pollinator with the stigma. Among the cyperoid genera in which the stylopodium occurs, insect pollination was reported for Eleocharis (Magalhães et al. 2005) and Rhynchospora (Thomas 1984). Further studies on pollination biology are 

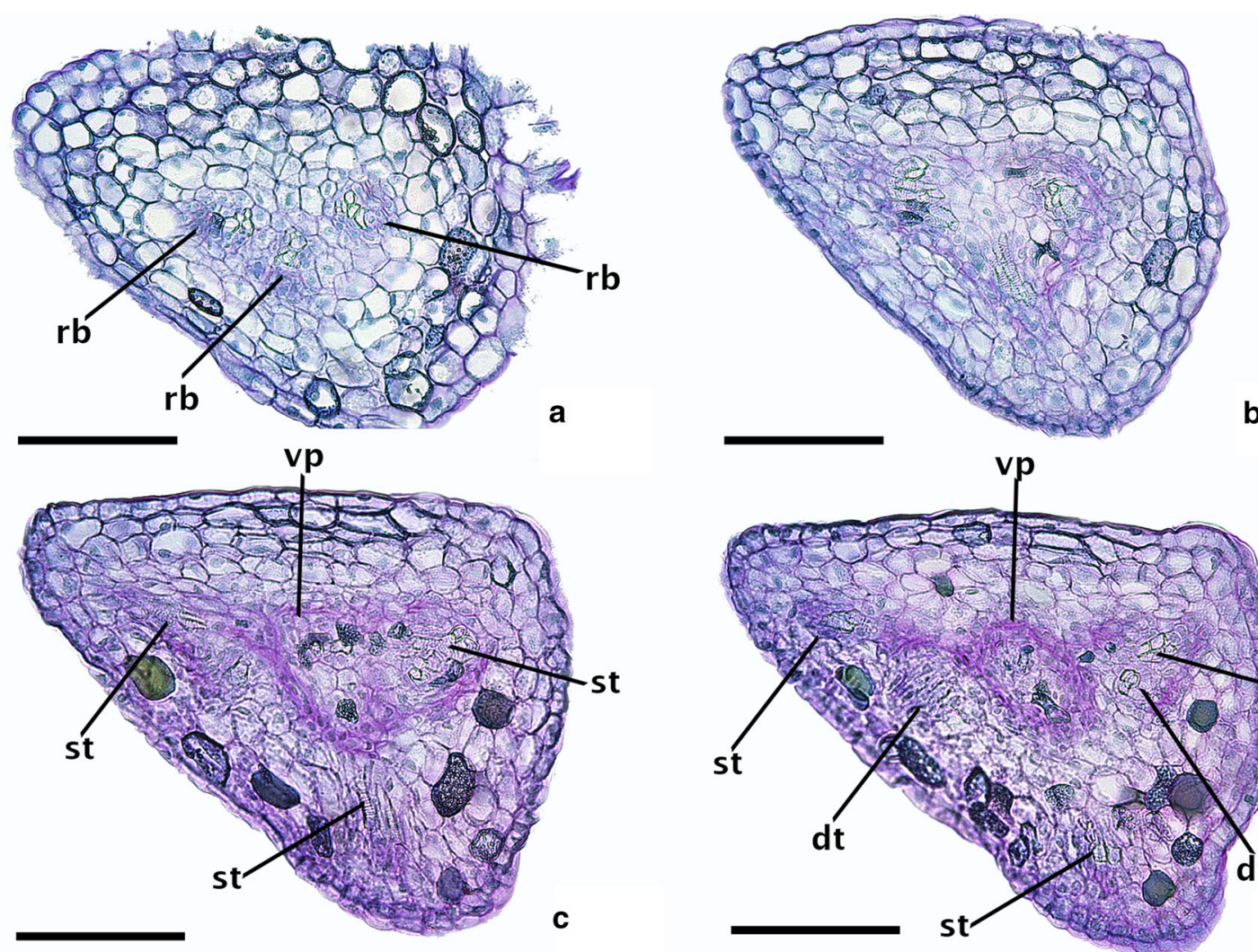

b
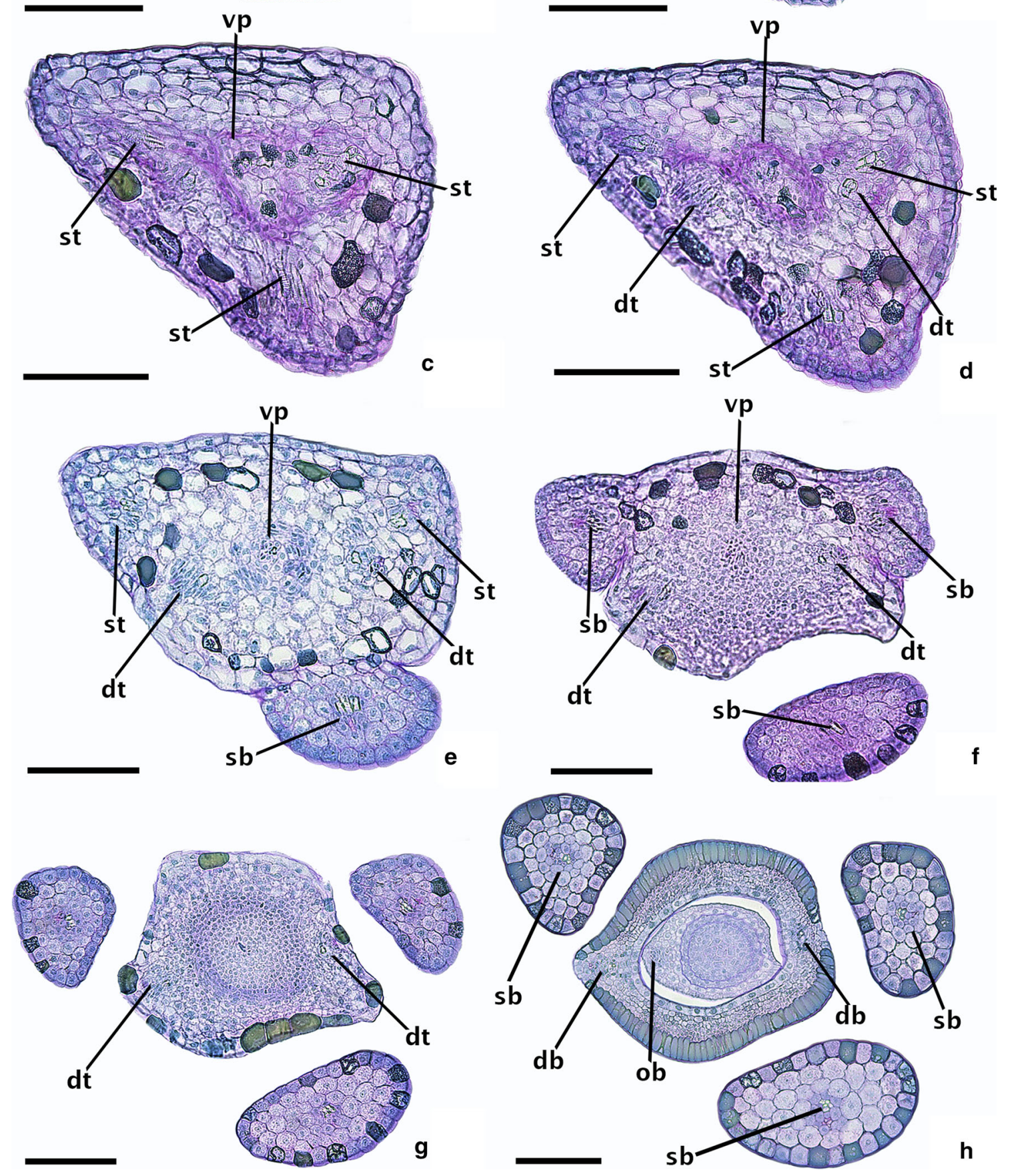


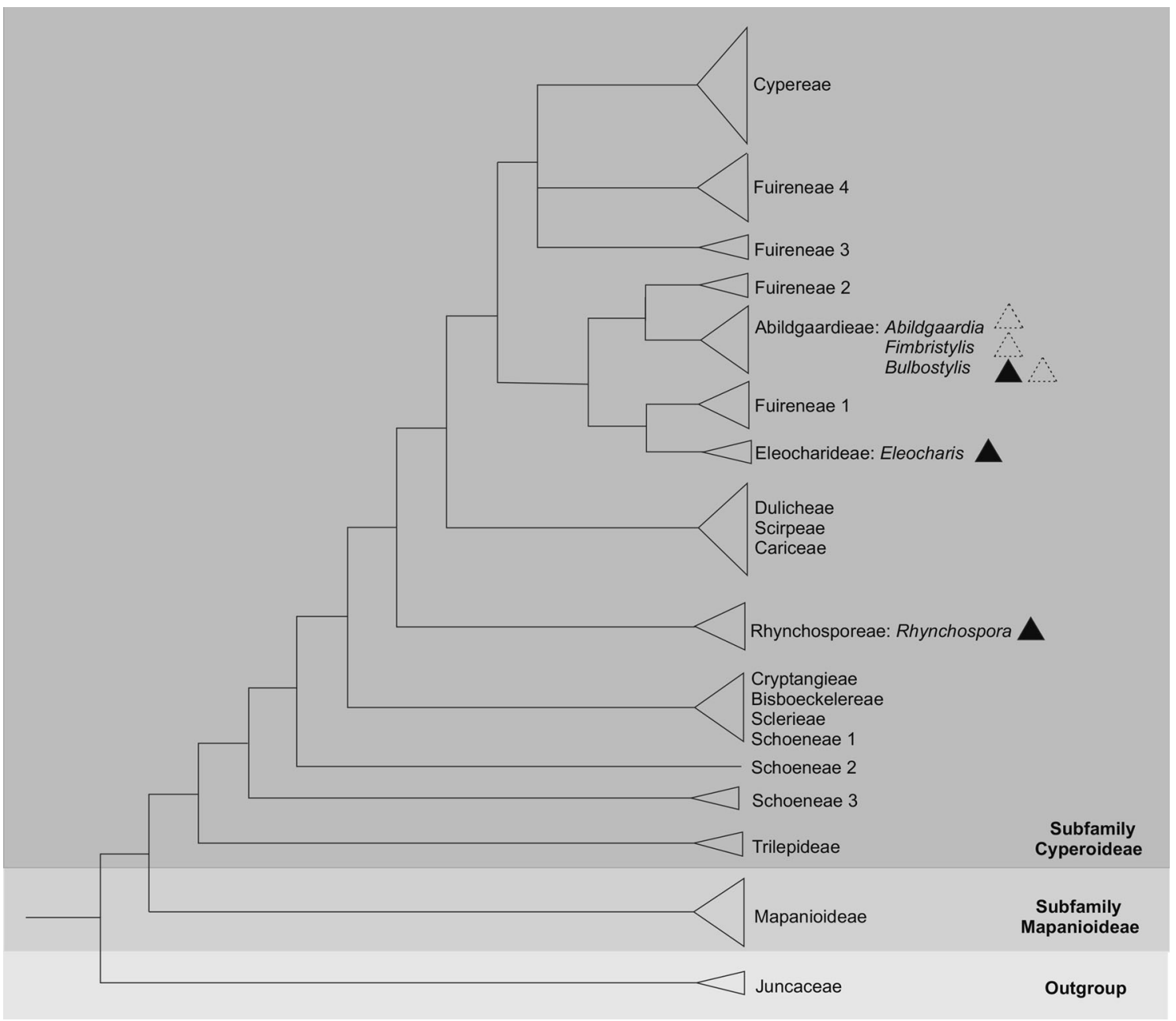

Fig. 8 Simplified cladogram of Cyperaceae, adapted from Muasya et al. (2009), showing the multiple origins of the stylopodium. The black triangle represents the presence of a persistent stylopodium, and the dotted triangle represents the presence of a deciduous stylopodium

thus necessary, especially for Abildgaardieae species, in which the stylopodium is deciduous.

\section{Floral vasculature}

The species here studied have a dorsiventrally flattened gynoecium, and their vasculature pattern is shown to be different from that previously described for the genus. According to Blaser (1941b), in Rhynchospora alba there are three receptacular bundles; after the divergence of the staminal traces, the two adaxial receptacular bundles split laterally and the bundles derived from them split again immediately. These latest derived bundles fuse with the remnants of the abaxial receptacular bundle, and the bundles formed by this fusion were designated as lateral carpellary bundles. According to the author, these peripheral lateral carpellary traces disappear below the level of fusion of the ventral carpellary bundles and by comparison with other species they were interpreted not only as vestiges of the persistent adaxial carpels, but also basal remnants of the abaxial aborted carpel. Blaser (1941b) also reported that other species of Rhynchospora such as $R$. macrostachya showed an identical general floral structure as that of $R$. alba, except for the absence of vestiges of the third carpel. In such species, there are only two receptacular bundles from which the staminal and carpellary traces arise. On the basis of the frequent presence of vestigial carpellary bundles, Blaser (1941a, b) concluded that dorsiventrally flattened gynoecium originated by reduction in the abaxial carpel, as previously suggested by other authors based on floral anatomical and ontogenetic studies (Baillon 1893; Snell 1936).

For $R$. consanguinea and $R$. pubera, we did not observe the presence of lateral carpellary traces, although the flowers of both species are supplied by three receptacular bundles. The rachilla is vascularised by two bundles, which split into three bundles at the receptacle level of all of the flowers. These three receptacular bundles form a vascular 
plexus before the divergence of the staminal and carpellary traces, as reported for Kyllinga nemoralis (Reynders et al. 2012). The gynoecium of $R$. consanguinea and $R$. pubera is vascularised by two dorsal carpellary bundles, which are laterally positioned. Also in $R$. corymbosa, the ovary and style are supplied by two dorsal vascular bundles that run in lateral positions, revealing the dorsiventrally flattened, dimerous nature of the gynoecium (Reynders et al. 2012).

According to Reynders et al. (2012), no carpel was lost during the evolution of the family, but the whole gynoecium development was reorganised through congenital fusion of the carpels and reducing the meristematic zone destined to become the gynoecium to (1) an annular primordium, in which the three vessels are the only evidence of the tricarpellate evolutionary origin of the gynoecium and (2) the former synascidiate zone of the fused carpels, which is reorganised into a meristematic zone corresponding with the floral apex, situated within the annular gynoecium wall primordium, from which the central ovule develops. According to the authors, the congenital fusion of the carpels and subsequent reorganisation of the gynoecial meristematic zone liberates the development of the gynoecium of the constraints of a carpellary organisation, allowing new positions and numbers of stigmas. In addition, due to the bidirectional development of the gynoecium vasculature, the number of dorsal carpellary bundles is related to the number of stigma primordia - not necessarily to the number of carpels-and corresponds to the number of vascular bundles within the rachilla (Reynders et al. 2012).

According to Reynders et al. (2012), in a dorsiventrally flattened dimerous gynoecium, the abaxial stamen bundle connects to both adaxial receptacular bundles, since the abaxial receptacular bundle is absent. However, in $R$. consanguinea and $R$. pubera, which also have a dorsiventrally flattened dimerous gynoecium, we demonstrate that the abaxial receptacular bundle is present, but the three receptacular bundles merge into an annular vascular plexus before the divergence of the staminal and carpellary traces and only two vessels supply the ovary. Although we observed no lateral carpellary traces, the presence of the abaxial receptacular bundle as a vestige of the third reduced carpel corroborates the hypothesis of Blaser (1941a, b). We agree with Reynders et al. (2012) that the annular ovary primordium and the bidirectional development of the pistil vasculature give the developing gynoecium an organisational freedom, but in combination with the reduction in one of the carpels (the abaxial one in the dorsiventrally flattened gynoecium). As reported for other Poales that also have reduced flowers grouped in dense spikelets such as Restionaceae (Ronse Decraene et al. 2002) and Poaceae (Phillipson 1985), we believe that the dorsiventrally flattened gynoecium resulted mainly by spatial pressures on the gynoecium during its development.
Since the meristematic zone for the gynoecium development is reduced, it is necessary a certain freedom of organisation, which is given by the congenital fusion of carpel primordia and the bidirectional development of the pistil vasculature, as demonstrated by Reynders et al. (2012) for a large number of cyperoid species.

\section{Conclusions}

Besides the morphological differences such as the presence of a perianth and type of anther dehiscence, the flowers of $R$. consanguinea and $R$. pubera are very similar anatomically. The congested inflorescences with unisexual flowers and light-coloured bracts/glumes and the great quantity of idioblasts containing phenolic compounds in the anthers and gynoecium of both species suggest insect pollination. In both species studied as well as in species of Eleocharis, Bulbostylis, Abildgaardia and Fimbristylis, the thickened style bases (stylopodium) have the same origin and similar anatomical features, indicating that they are homologous and that such structure appeared several times in Cyperoideae. The gynoecium vasculature of $R$. consanguinea and $R$. pubera is different of that previously described for other species of Rhynchospora, and the presence of an abaxial receptacular bundle may be interpreted as a vestige of the tricarpellate ancestral state. The reduction in the abaxial carpel, as proposed by Blaser (1941a, b), in combination with the congenital fusion of carpels and bidirectional development of pistil vasculature, as described by Reynders et al. (2012), is probably responsible for the appearance of the dorsiventrally flattened dimerous gynoecium during the evolution of the family.

Acknowledgments The authors thank CNPq-Conselho Nacional de Desenvolvimento Científico e Tecnológico (Grant Numbers 130773/2013-1, 168277/2014-0 and 301692/2010-6) and FAPESPFundação de Amparo à Pesquisa do Estado de São Paulo (Grant Number 2011/11536-3) for financial support, and Dr Alessandra Ike Coan for collecting the samples of Rhynchospora consanguinea. We also thank Dr Alexander Vrijdaghs and an anonymous reviewer for their comments that improved the text.

\section{Compliance with ethical standards}

Conflict of interest The authors declare that there is no conflict of interest.

\section{References}

Araújo AC (2001) Revisão taxonômica de Rhynchospora Vahl. sect. Pluriflorae Kük. (Cyperaceae). PhD Thesis, Universidade de São Paulo, São Paulo 
Araújo AC, Longhi-Wagner HM, Thomas WW (2003) New unicapitate species of Rhynchospora (Cyperaceae) from South America. Brittonia 55:30-36. doi:10.1663/0007-196X(2003)055

Baillon H (1893) Notes organogeniques et organographiques sur les Carex. Bull Soc Linn Paris 2:1097-1101

Blaser HW (1941a) Studies in the morphology of the Cyperaceae I. Morphology of the flowers. Scirpoid genera. Amer J Bot 28:542-551. doi: $10.2307 / 2437000$

Blaser HW (1941b) Studies in the morphology of the Cyperaceae I. Morphology of flowers. Rhynchosporoid genera. Amer J Bot 28:832-838. doi:10.2307/2436669

Bruhl JJ (1995) Sedge genera of the world: relationships and a new classification of the Cyperaceae. Austral Syst Bot 8:125-305. doi:10.1071/SB9950125

Costa ACG, Machado IC (2012) Flowering dynamics and pollination system of the sedge Rhynchospora ciliata (Vahl) Kükenth (Cyperaceae): Does ambophily enhance its reproductive success? Pl Biol 14:881-887. doi:10.1111/j.1438-8677.2012.00574.x

Dobson HEM, Bergström G (2000) The ecology and evolution of pollen odors. Pl Syst Evol 222:63-87. doi:10.1007/BF00984096

Eiten LT (1976) Inflorescence units in the Cyperaceae. Ann Missouri Bot Gard 63:81-112. doi:10.2307/2395224

Feder N, O'Brien TP (1968) Plant microtechnique: some principles and new methods. Amer J Bot 55:123-142. doi:10.2307/ 2440500

Gerrits PO, Smid L (1983) A new, less toxic polymerization system for the embedding of soft tissues in glycol methacrylate and subsequent preparing of serial sections. J Microscopy 132:81-85. doi:10.1111/j.1365-2818.1983.tb04711.x

Gil ASB, Bove CP (2007) Eleocharis R.Br. (Cyperaceae) no Estado do Rio de Janeiro, Brasil. Biota Neotrop 7:2-31. doi:10.1590/ S1676-06032007000100020

Goetghebeur P (1998) Cyperaceae. In: Kubitzki K (ed) The families and genera of vascular plants, vol 4. Springer, Berlin, pp 141-190

Gonzalez AM, López MG (2010) Development and morphology of the gynoecium and nutlet in two South-American Bulbostylis (Cyperaceae) species. Flora 205:211-220. doi:10.1016/j.flora. 2009.02.002

Govaerts R, Simpson DA, Goetghebeur P, Wilson KL, Egorova T, Bruhl J (2007) World checklist of Cyperaceae (Sedges). Royal Botanic Gardens, Kew

Govindarajalu E (1969) Observations on new kinds of silica deposits in Rhynchospora spp. Proc Indian Acad Sci Pl Sci 70:28-36. doi:10.1007/BF03052192

Guaglianone ER (2001) Contribución al estudio del género Rhynchospora (Cyperaceae) V. sección Longirostres em América Austral. Darwiniana 39:287-342

Johansen DA (1940) Plant microtechnique. McGraw-Hill Book Co, New York

Kükenthal G (1949) Vorarbeiten zu einer Monographie der Rhynchosporoideae. Bot Jahrb Syst 75:90-195

Kükenthal G (1950) Vorarbeiten zu einer Monographie der Rhynchosporoideae. Bot Jahrb Syst 74:375-509

Kükenthal G (1951) Vorarbeiten zu einer Monographie der Rhynchosporoideae. Bot Jahrb Syst 75:273-314

Kükenthal G (1952) Vorarbeiten zu einer Monographie der Rhynchosporoideae. Bot Jahrb Syst 75:451-497

Kukkonen I (1984) On the inflorescence structure in the family Cyperaceae. Ann Bot Fenn 21:257-264

Leppik EE (1995) Dichromena ciliata, a noteworthy entomophilous plant among Cyperaceae. Amer J Bot 42(5):455-458. doi:10. 2307/2438794

Lucero LE, Vegetti AC (2012) Inflorescence structure in Rhynchospora Vahl (Cyperaceae). Flora 207:47-56. doi:10.1016/j. flora.2011.10.003
Lucero LE, Vegetti AC, Reinheimer R (2014) Evolution and development of the spikelet and flower of Rhynchospora (Cyperaceae). Int J Pl Sci 175:186-201. doi:10.1086/674317

Magalhães AF, Ruiz ALTG, Flach A, Faria AD, Magalhães EG, Amaral MCE (2005) Floral scent of Eleocharis elegans (Kunth) Roem. \& Schult. (Cyperaceae). Biochem Syst Ecol 33:675-679. doi:10.1016/j.bse.2004.12.004

Martins S, Scatena VL (2011) Bundle sheath ontogeny in Kranz and non-Kranz species of Cyperaceae (Poales). Austral $\mathrm{J}$ Bot 59:554-562. doi:10.1071/BT11108

Martins S, Pilatti V, Vegetti A, Scatena VL (2012) Do leaves in Cyperoideae (Cyperaceae) have a multiple epidermis or a hypodermis? Flora 207:341-345. doi:10.1016/j.flora.2012.02.004

Metcalfe CR (1969) Anatomy as an aid to classifying the Cyperaceae. Amer J Bot 56:782-790. doi:10.2307/2440598

Muasya AM, Simpson DA, Verboom GA, Goetghebeur P, Naczi RFC, Chase MW, Smets E (2009) Phylogeny of Cyperaceae based on DNA sequence data: current progress and future prospects. Bot Rev 75:52-66. doi:10.1007/s12229-008-9019-3

O'Brien TP, Feder N, McCully ME (1964) Polychromatic staining of plant cell walls by toluidine blue O. Protoplasma 59:368-373. doi:10.1007/BF01248568

Phillipson WR (1985) Is the grass gynoecium monocarpellary? Amer J Bot 72:1854-1961. doi:10.2307/2443612

Prutsch J, Schardt A, Schill R (2000) Adaptations of an orchid seed to water uptake and storage. Pl Syst Evol 220:69-75. doi:10.1007/ BF00985371

Reutemann AG, Vegetti AC, Pozner R (2012) Structure and development of the style base in Abildgaardia, Bulbostylis and Fimbristylis (Cyperaceae, Cyperoideae, Abildgaardieae). Flora 207:223-236. doi:10.1016/j.flora.2012.01.008

Reynders M, Vrijdaghs A, Larridon I, Huygh W, Leroux O, Muasya AM, Goetghebeur P (2012) Gynoecial anatomy and development in Cyperoideae (Cyperaceae, Poales): congenital fusion of carpels facilitates evolutionary modifications in pistil structure. Pl Ecol Evol 145:96-125. doi:10.5091/plecevo.2012.675

Ronse Decraene LP, Linder HP, Smets EF (2002) Ontogeny and evolution of the flowers of South African Restionaceae with special emphasis on the gynoecium. Pl Syst Evol 231:225-258. doi:10.1007/s006060200021

Saunders ER (1937) Floral morphology, vol 1. Heiffer, Cambridge

Simpson DA, Muasya AM, Alves M, Bruhl JJ, Dhooge S, Chase MW, Furness CA, Ghamkhar K, Goetghebeur P, Hodkinson TR, Marchant AD, Nieuborg R, Reznicek AA, Roalson EH, Smets E, Starr JR, Thomas WW, Wilson KL, Zhang X (2007) Phylogeny of Cyperaceae based on DNA sequence data: a new $r b c \mathrm{~L}$ analysis. Aliso 23:72-83. doi:10.5642/aliso.20072301.09

Snell RS (1936) Anatomy of the spikelet and flowers of Carex, Kobresia and Uncinia. Bull Torrey Bot Club 63:277-295. doi: $10.2307 / 2480780$

Stevens PF (2016) Angiosperm phylogeny website. Version 12, July 2012. http://www.mobot.org/MOBOT/research/APweb/. Accessed 4 Nov 2016

Strong MT (2006) Taxonomy and distribution of Rhynchospora (Cyperaceae) in the Guianas, South America. Contr US Natl Herb 53:1-225

Swan GA, Richards AJ (2007) The Eleocharis mamillata H. Lindb. fil. aggregate (Cyperaceae) in the British Isles. Watsonia 26:317-325

Thomas WW (1984) The systematics of Rhynchospora sect. Dichromena. Mem New York Bot Gard 37:1-116. doi:10.2307/4109645

Thomas WW (1992) A synopsis of Rhynchospora (Cyperaceae) in Mesoamerica. Brittonia 44:14-44. doi:10.2307/2807437

Thomas WW, Araujo AC, Alves MV (2009) A preliminary molecular phylogeny of the Rhynchosporeae (Cyperaceae). Bot Rev 75:22-29. doi:10.1007/s12229-008-9023-7 
Vrijdaghs A, Goetghebeur P, Muasya AM, Smets E, Caris P (2004) The nature of the perianth in Fuirena (Cyperaceae). S African J Bot 70:587-594. doi:10.1016/S0254-6299(15)30196-4

Vrijdaghs A, Goetghebeur P, Muasya AM, Caris P, Smets E (2005a) Floral ontogeny in Ficinia and Isolepis (Cyperaceae), with focus on the nature and origin of the gynophore. Ann Bot (Oxford) 96:1247-1264. doi:10.1093/aob/mci132

Vrijdaghs AC, Caris P, Goetghebeur P, Smets E (2005b) Floral ontogeny in Scirpus, Eriophorum and Dulichium (Cyperaceae), with special reference to the perianth. Ann Bot (Oxford) 95:1199-1209. doi:10.1093/aob/mci276
Vrijdaghs A, Muasya AM, Goetghebeur P, Caris P, Nagels A, Smets E (2009) A floral ontogenetic approach to homology questions within the Cyperoideae (Cyperaceae). Bot Rev 75:30-51. doi:10. 1007/s12229-008-9021-9

Wragg PD, Johnson SD (2011) Transition from wind pollination to insect pollination in sedges: experimental evidence and functional traits. New Phytol 191:1128-1140. doi:10.1111/j.14698137.2011.03762.x 